\section{In Vitro Propagation of Agave americana by Indirect Organogenesis}

Carlos Alberto Lecona-Guzmán and Sheila Reyes-Zambrano

Laboratorio de Biotecnología Vegetal, Instituto Tecnológico de Tuxtla Gutiérrez, Carretera Panamericana kilómetro 1080, Terán, CP 29050, Tuxtla Gutiérrez, Chiapas, México

\section{Felipe Alonso Barredo-Pool}

Unidad de Biotecnología Centro de Investigación Científica de Yucatán, Calle $43 N^{\circ} 130$, Colonia Chuburná de Hidalgo, CP 97200, Mérida, Yucatán, Mexico

\section{Miguel Abud-Archila, Joaquín Adolfo Montes-Molina, Reiner Rincón- Rosales, and Federico Antonio Gutierrez-Miceli ${ }^{1}$ \\ Laboratorio de Biotecnología Vegetal, Instituto Tecnológico de Tuxtla Gutiérrez, Carretera Panamericana kilómetro 1080, Terán, CP 29050, Tuxtla Gutiérrez, Chiapas, México}

Additional index words. 6-benzyl adenine, 2,4-dicholorophenoxyacetic acid, callus induction, shoots

\begin{abstract}
Factors such as slow growth, low rates of sexual and asexual reproduction, and viability of seeds among others limit the massive propagation of Agave americana $\mathbf{L}$. by conventional methods. In this study, callus induction and shoot proliferation was determined in A. americana using Murashige and Skoog (MS) medium supplemented with dicholorophenoxyacetic acid (2,4-D) and 6-benzyl adenine (BA). Meristematic tissue was used as the explants, and were placed on MS medium supplemented with $30.0 \mathrm{~g} \cdot \mathrm{L}^{-1}$ sucrose with $0.11,0.18$, or $0.45 \mu M$ 2,4-D and 11.0, 22.0, 38.2, 44.0, 58.7, or 73.3 $\mu \mathrm{M}$ BA. Treatments were implemented according to factorial experimental design $3 \times 6$. After 1 month, the number of explants with callus was determined, whereas the numbers of shoots per explant were monitored after $4,16,20$, and 36 weeks. The maximum percent of explants with callus was obtained with $0.11 \mu_{M} 2,4-D$ and 58.7 and $73.3 \mu \mathrm{M} B A$, whereas the maximum numbers of shoots per explant (71) were obtained with $0.11 \mu M$ 2,4-D and 73.3 $\mu$ м BA. The effect of different concentrations of indolebutyric acid (IBA) in the rooting of shoots was evaluated. There were no significant effects of IBA on the number of roots, root length, and axillary roots. Plantlets were acclimatized in the glasshouse and they did not show any phenotypic alteration. This is a highly efficient protocol for the in vitro propagation of $A$. americana via indirect organogenesis.
\end{abstract}

The Agave is an important species native to semiarid and arid regions, the origin center being Mexico. These plant populations spread from the southwestern United States through Central America, the Caribbean, and into northern South America (Good-Avila et al., 2006). Species of the genus Agave are very important owing to the wide variety of uses of these plants, as they produce food and natural fibers (Rivera et al., 2010). All species of the family Agavaceae are native to the American continent and are classified into eight genera. It is assumed that $75 \%$ of all species belonging to the Agavaceae family are found in Mexico with 55\% being endemic (García et al., 2010). The genus Agave, belonging to the family Agavaceae, arose

Received for publication 3 Dec. 2015. Accepted for publication 4 May 2016.

This research was supported by Project "Infraestructura 251805" "Consejo Nacional de Ciencia y Tecnologiìa" (CONACyT, Mexico).

${ }^{1}$ Corresponding author. E-mail: fgmiceli@gmail.com. $\approx 15$ million years ago (Rocha et al., 2005). Agave americana is an important species with different uses, native to the southern United States and Mexico, widely cultivated throughout the world, Although Agave americana $\mathrm{L}$. is not yet a "threatened" species in Mexico, its distribution has been reduced as its natural habitat is decreasing as a result of explotation, especially in southern Mexico. An alternative to solve this problem is to generate technological packages for the artificial reproduction of the species to ensure the production of highly productive plants and the quality of them through control of growing conditions which will allow recovery of populations that have been diminished by the looting and destruction of habitat. Agave americana is of economic importance because it is used for the production of an alcoholic beverage called "comiteco." All available plants for the production of this liqueur come from vegetative propagation by suckers. To ensure the availability of adult plants required for the production of liquor, it is necessary to establish measures to promote the spread and protection of populations. Slow growth, low rate of asexual reproduction, and sexual reproduction limited by problems of pollination and seed viability are factors that hinder the massive multiplication of agaves by conventional methods. Besides, these factors limit the potential for improvement of cultivated species (Chen et al., 2014; Portillo et al., 2007; Robert et al., 1992). The in vitro $A$. americana reproduction is an alternative that can overcome the low amount of raw material to date and lead to the generation of protocols for the micropropagation of the species. In vitro methods can be used to propagate and preserve plant species when seed-based methods are inadequate (Pence, 2011). Successful propagation depends on several steps, including obtaining cultures free of pathogenic bacteria and fungi, establishment of shoot producing or embryogenic cultures, rooting of shoots or the outgrowth of embryos into plants, and the acclimatization of those plants to ex vitro conditions (Pospíśilová et al., 1999). Callus culture might be a useful technique to cultivate $A$. americana, offering the potential to produce plants of the desired clone and might also serve as a starting point for future plant improvement through molecular biotechnology. Several studies have been reported on the micropropagation of Agave species such as Agave fourcroydes (Robert et al., 1987), Agave cantala (Binh et al., 1990), Agave parrasana (SantacruzRuvalcaba et al., 1999), Agave victoriaereginae (Martínez-Palacios et al., 2003; Rodríguez-Garay et al., 1996), Agave sisalana (Hazra et al., 2002; Nikam, 1997; Nikam et al., 2003), and Agave tequilana (CastroConcha et al., 1990; Robert et al., 1992). Garriga et al. (2010) reported that the combination of 6-N-Bencilaminopurina (BAP) at a concentration of $0.75 \mathrm{mg} \cdot \mathrm{L}^{-1}$ and $1 \mathrm{mg} \cdot \mathrm{L}^{-1}$ IBA had a significant effect on survival of the explant in establishing medium for shoot proliferation. However, combining 0.5 or $0.75 \mathrm{mg} \cdot \mathrm{L}^{-1}$ Thidiazuron with $1.0 \mathrm{mg} \cdot \mathrm{L}^{-1}$ BAP and $1.0 \mathrm{mg} \cdot \mathrm{L}^{-1} \mathrm{IBA}$ in the MS basal medium increased shoot multiplication percentage. Somatic embryogenesis has been reported by Portillo et al. (2007) in $A$. tequilana Weber blue cultivar using leaf as the source of explant and MS medium supplemented with $9.0 \mu \mathrm{m}$ of $2,4-\mathrm{D}$ and $1.3 \mu \mathrm{M}$ BA. The obtaining embryogenic lines using callus induced on MS medium (SantacruzRuvalcaba and Portillo, 2009). Shoot proliferation was reported in $A$. parrasana Berger using MS medium supplemented with $\mathrm{L}_{2}$ vitamins and $13.3 \mu \mathrm{M}$ BA (SantacruzRuvalcaba et al., 1999). Tejavathi et al. (2007) induced somatic embryos from callus culture of Agave vera-cruz Mill. in MS medium supplemented with $\mathrm{L}_{2}$ vitamins, 4.52 $\mu_{\mathrm{M}}$ 2,4-D and 5.37 $\mu \mathrm{M}$ 1-naphthaleneacetic acid (NAA). The MS medium was supplemented with $5.37 \mu \mathrm{M}$ NAA, $0.91 \mu \mathrm{M}$ Zeatin (ZEA) and $40 \mathrm{~g} \cdot \mathrm{L}^{-1}$ sucrose for embryo maturation and re-differentiation. Indirect somatic embryogenesis has been reported in A. angustifolia Haw from callus 
induced from zygotic embryos cultivated in quarter-strength MS medium supplemented with $60 \mathrm{~g} \cdot \mathrm{L}^{-1}$ sucrose, $3.0 \mathrm{mg} \cdot \mathrm{L}^{-1}$ 2,4-D, and $1.0 \mathrm{mg} \cdot \mathrm{L}^{-1} \mathrm{BA}$ (Arzate-Fernández and Mejía-Franco, 2011). Shoots were obtained in Agave grijalvensis B. Ullrich in MS medium plus $8.2 \mu \mathrm{M}$ BA (Sánchez-Urbina et al., 2008). For somatic embryo induction, MS medium supplemented with $22.0 \mu \mathrm{M}$ BA and $2.6 \mu \mathrm{M}$ NAA was used (Santíz et al., 2012). Recently, Chen et al. (2014) reported a protocol for shoot regeneration (18.0 shoots/ explant) using MS medium supplemented with $13.32 \mu \mathrm{M}$ BA using meristems as explants. In this study, the effect of different concentrations of 2,4-D and BA on the induction of $A$. americana callus from meristem and on the number of shoots per callus were investigated. In addition, the effect of IBA on root induction was studied to obtain complete plantlets. The process of cell dedifferentiation can be seen by histological studies and determine regeneration pathways, and also confirms the presence of meristematic structures, which when divided by mitosis give rise to new structures.

\section{Materials and Methods}

Explant source and disinfection. The $A$. americana plants used in this study were obtained from a collection at the experimental site of Tuleaito, located in Comitan (NL $16^{\circ} 15^{\prime} 04^{\prime}$, WL $\left.92^{\circ} 08^{\prime} 03^{\prime \prime}\right)$, at an altitude of 1622 m.a.s.l. (Chiapas, México) during the period June-August. Leaves, stems, and roots were removed from 8-week-old plants, leaving only the main body which contained the meristem. The main bodies were washed and disinfected with soap (Axion ${ }^{\circledR}$ ) and water for $5 \mathrm{~min}$. The dissection of the explants to obtain segments of $\approx 1.5 \mathrm{~cm}$ was performed in a laminar flow hood. Explants were submerged in $0.5 \%$ agrimicin 500 (Arista Life Science) solution mixed with $0.5 \%$ captan (Pfizer) for $20 \mathrm{~min}$, and rinsed three times with sterile distilled water for $5 \mathrm{~min}$. They were then immersed in $70 \%$ ethanol for $5 \mathrm{~min}$, and then in a solution of commercial sodium hypochlorite at $30 \%$ for $20 \mathrm{~min}$, and rinsed again three times $(1 \mathrm{~min})$ in sterile distilled water (Vázquez-Molina et al., 2005). They were later submerged in a $0.1 \% \mathrm{HgCl}_{2}$ solution for $10 \mathrm{~min}$, and rinsed three times with sterile distilled water. As the last step, the explants were submerged in a $3 \%(\mathrm{w} / \mathrm{v})$ $\mathrm{CaCl}_{2} \mathrm{O}_{2}$ solution for $20 \mathrm{~min}$ and then washed three times with sterile distilled water for 5 min (Vázquez-Molina et al., 2005).

Callus induction and shoot regeneration. Explants were directly placed in MS (Murashige and Skoog, 1962) medium supplemented with different combinations of $0.11 \mu \mathrm{M}$ 2,4-D (Fluka ${ }^{\circledR}$ ), and 58.7 and $73.3 \mu \mathrm{M} \mathrm{BA}$ $\left(\right.$ Sigma $\left.{ }^{\circledR}\right)$. The hormone-free MS medium was a control. A culture vessel containing $20 \mathrm{~mL}$ of medium with four explants was considered as an experimental unit and the experiment was repeated five times. The culture medium contained $30 \mathrm{~g} \cdot \mathrm{L}^{-1}$ sucrose and $2.5 \mathrm{~g} \cdot \mathrm{L}^{-1}$ phytagel $\left(\right.$ Sigma $\left.^{\circledR}\right)$. The $\mathrm{pH}$ was adjusted to 5.7 before autoclaving at $121{ }^{\circ} \mathrm{C}$ and $1.2 \mathrm{~kg} \cdot \mathrm{cm}^{-2}$ pressure for $15 \mathrm{~min}$. Callus formation was evaluated every month and subculturing was done every 2 months. Callus cultures were transferred to MS hormonefree medium after the third subculture to induce shoot regeneration after 2 months. Cultures were maintained at $25{ }^{\circ} \mathrm{C}$ under continuous illumination $\left(35 \mathrm{mmol} \cdot \mathrm{m}^{-2} \cdot \mathrm{s}^{-1}\right)$ with fluorescent lights. Regenerated shoots were separated from the callus and transferred to test tubes $(25 \times 130 \mathrm{~mm})$, each containing $10 \mathrm{ml}$ half-strength MS medium containing $30 \mathrm{~g} \cdot \mathrm{L}^{-1}$ sucrose and $2.5 \mathrm{~g} \cdot \mathrm{L}^{-1}$ phytagel. Cultures were maintained at $25{ }^{\circ} \mathrm{C}$ under continuous illumination $\left(35 \mathrm{mmol} \cdot \mathrm{m}^{-2} \cdot \mathrm{s}^{-1}\right)$

Rooting and acclimatization of plantlets. Plantlets were rooting and acclimatization according to Reyes-Zambrano et al. (2016). Two hundred and fifty plantlets with a welldeveloped root system were washed in running water to remove phytagel and transferred to unicel pots $(12 \times 10 \mathrm{~cm})$ (one plantlet per unicel pot) containing peatmoss and agrolite mixture $(1: 1)$ for acclimatization. Plantlets were grown in the greenhouse with temperatures that ranged

Table 1. Effect of 2,4-D and BA on callus induction and shoot regeneration in Agave americana L.

\begin{tabular}{|c|c|c|c|c|c|c|c|}
\hline \multirow[b]{3}{*}{ Treatment } & & & \multirow{3}{*}{$\frac{\begin{array}{c}\text { Explant } \\
\text { with callus }\end{array}}{(\%)}$} & \multicolumn{4}{|c|}{ No. of shoots per callus } \\
\hline & 2,4-D & BA & & 4 & 16 & 20 & 36 \\
\hline & \multicolumn{2}{|c|}{$(\mu \mathrm{M})$} & & \multicolumn{4}{|c|}{ (wk) } \\
\hline$\overline{1}$ & 0.11 & 58.7 & $80 \mathrm{a}$ & $14.0 \mathrm{a}$ & $39.0 \mathrm{a}$ & $33.0 \mathrm{a}$ & $65 \mathrm{a}$ \\
\hline 2 & 0.11 & 73.3 & $80 \mathrm{a}$ & $10.0 \mathrm{a}$ & $40.0 \mathrm{a}$ & $31.0 \mathrm{a}$ & $71 \mathrm{a}$ \\
\hline 3 & 0 & 0 & $0 \mathrm{~b}$ & $0 \mathrm{~b}$ & $0 \mathrm{~b}$ & $0 \mathrm{~b}$ & $0 \mathrm{~b}$ \\
\hline$\underline{\operatorname{LSD}}(0.05)^{\mathrm{z}}$ & & & 5.7 & 2.8 & 4.4 & 8.8 & 7.3 \\
\hline
\end{tabular}

2,4-D = dicholorophenoxyacetic acid; $\mathrm{BA}=6$-benzyl adenine.

${ }^{\mathrm{z}} \mathrm{LSD}=$ least significant difference $(P<0.05)$. Values with the same letter are not significantly different between the treatments.

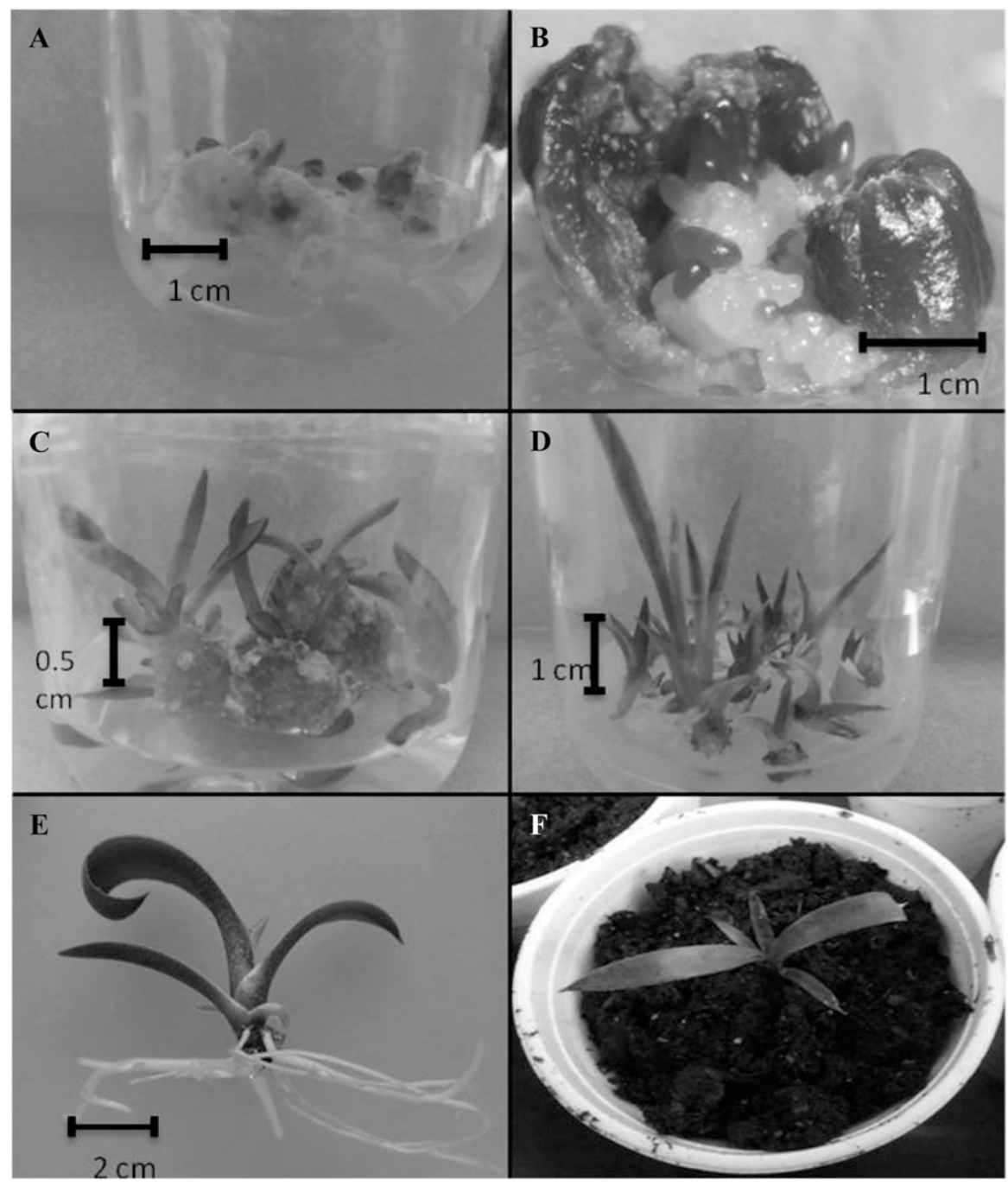

Fig. 1. In vitro regeneration of Agave americana L. plantlets. (A) Callus induced from meristematic tissue, (B) adventitious bud formation from callus, (C) shoots regenerated from callus, (D) plantlets derived from callus, $(\mathbf{E})$ plantlets with roots, and $(\mathbf{F})$ plants growing in the soil. 
from $18 \pm 2{ }^{\circ} \mathrm{C}$ for 4 weeks to $20-26{ }^{\circ} \mathrm{C}$ for 8 weeks. They were then transferred to nearcommercial greenhouse conditions where temperatures fluctuated between $30-35{ }^{\circ} \mathrm{C}$ in daytime and $16-24^{\circ} \mathrm{C}$ at night. The plantlets were irrigated every third day.

Histological analysis. For detailed anatomical studies, the samples were fixed in formalin/acetic acid/ethanol/water (10:5:50:35, by volume) for $48 \mathrm{~h}$, kept at $4{ }^{\circ} \mathrm{C}$, rinsed with distilled water, and dehydrated in a graded ethanol series from $30 \%, 50 \%, 70 \%, 85 \%$, $96 \%$, and absolute ethyl alcohol (v/v). The samples were infiltrated and embedded in plastic resin JB-4 Embedding $\mathrm{Kit}^{\circledR}$ (glycol methacrylate; Polysciences, Los Angeles, $\mathrm{CA}$ ), according to the instructions of the manufacturer. Longitudinal sections that were $3 \mu \mathrm{m}$ thick were cut using a microtome (Microm HM 325; Thermo Scientific, Walldorf, Germany). Sections were acidified for $30 \mathrm{~min}$ with periodic acid $(1 \% \mathrm{w} / \mathrm{v})$, rinsed with distilled water repeatedly, and stained for $20 \mathrm{~min}$ with Schiff reagent as described by McManus (1961). Finally, the samples were stained for 5 min with 7\% (w/v) Naphtol blue black mounted in Poly-mount (Polysciences, Inc.), ase spe and photographed using a microscope Scope.A1; Carl Zeiss, AxioCam Icc 5.

Data analysis. SAS statistical software (SAS Institute, 1990) was used to analyze data using a confidence limit of $5 \%$. The linear and quadratic values of all factors and the interactions between them were tested.

\section{Results}

Callus induction. Callus formation was obtained in all treatments. Explant percentage with callus was not affected by the different combinations of 2,4-D and BA, and varied from $0 \%$ in treatment 3 to $80 \%$ in the 1 and 2 treatments $(P<0.05)$ (Table 1$)$.

Induction of shoots and plant regeneration. The number of shoots was 71 with $0.11 \mu \mathrm{M}$ 2,4-D plus $73.3 \mu \mathrm{M}$ BA (Table 1). Callus were obtained after 4 weeks (Fig. 1A and B). Adventitious bud were observed and shoots were produced after 12 weeks callus induction (Fig. 1C). Plantlets derived from callus were observed after 16 weeks (Fig 1D).

Rooting and acclimatization of plantlets. Rooting was recorded after 4 weeks. Axillary roots were observed after 11 weeks (Fig. 1E). The plantlets were acclimatized successfully (Fig. 1F) with a survival rate of $100 \%$. The plantlets did not show any phenotypic variation.

Histological analysis. The histological analysis done with callus derived of treatment with $73.3 \mu \mathrm{M}$ BA and $0.11 \mu \mathrm{M}$ 2,4-D confirm adventitious shoot formation in $A$. americana (Fig. 2A). Meristematic zones were observed (Fig. 2B) with high mitotic activity and vascular bundles (Fig. 2C). Cells from organogenic centers were similar to meristematic cells of axillary buds (Fig. 2D).

\section{Discussion}

Efficient protocols for micropropagation have been obtained through axillary shoots
(Madrigal-Lugo et al., 1989; Robert et al., 1992), organogenesis (Hazra et al., 2002; Nikam 1997; Robert et al., 1987; ValenzuelaSánchez et al., 2006), or somatic embryogenesis (Martínez-Palacios et al., 2003; Nikam et al., 2003; Rodríguez-Garay et al., 1996). All these protocols are evidence that the in vitro regeneration of each Agave species is dependent on plant growth regulators, a fact that has been confirmed by the results of this study. However, the micropropagation efficiency is variable. Nikam (1997) reported 5.7 shoots per explant with $0.5 \mathrm{mg} \cdot \mathrm{L}^{-1}$ kinetin in A. sisalana. SantacruzRuvalcaba et al. (1999) obtained 22.0 shoots per explant with $3.0 \mathrm{mg} \cdot \mathrm{L}^{-1} \mathrm{BA}$, whereas Martínez-Palacios et al. (2003) found 2.2 shoots per explant in $A$. victoriae-reginae cultivated in MS medium plus $1.0 \mathrm{mg} \cdot \mathrm{L}^{-1}$ BA. Axillary meristems were used as explants, and results are evidence of the heterogeneous response in Agave species. Valenzuela-Sánchez et al. (2006) found 19.5 shoots per explant in A. tequilana with plantlet dedifferentiation through indirect organogenesis. The plant growth regulators play an important role in controlling the morphogenetic response of in vitro cultures. Endogenous growth regulator content is known to differ from one meristematic center of the callus to another (Norton, 1986), with the balance between the endogenously and exogenously supplied hormones determining the morphogenetic response. Tejavathi et al. (2007) obtained embryogenic callus in $A$. vera-cruz in MS medium supplemented with

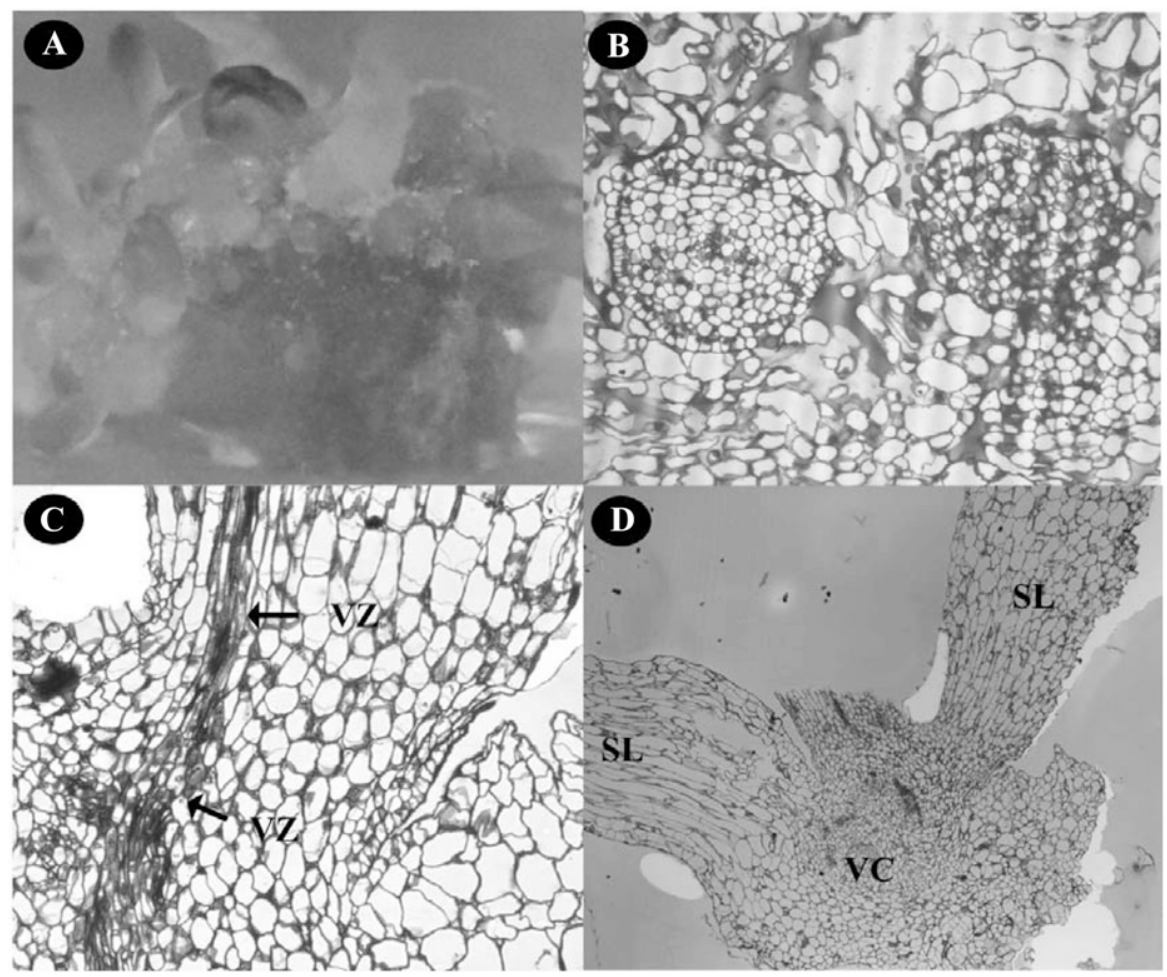

Fig. 2. Histological analysis of organogenesis indirect of Agave americana L. (A) Callus induced from meristematic tissue at 36 weeks of culture, (B) formation of meristematic zones, (C) vascular tissue, and (D) a development shoot derived from meristematic tissue consists of shoot apical meristem connected with vascular tissue. Sheath leaves (SL), vascular connection (VC), vascular zone (VZ). 
Infante et al., 2003), A. tequilana (SantacruzRuvalcaba and Portillo, 2009; Torres-Morán et al., 2010), A. parrasana (SantacruzRuvalcaba et al., 1999), A. vera-cruz (Tejavathi et al., 2007), A. angustifolia (Arzate-Fernández and Mejía-Franco, 2011), and A. grijalvensis (Sánchez-Urbina et al., 2008; Santíz et al., 2012). The rooting of shoots of A. americana was not a significant factor. Rooting response was the same in comparison with other Agave species, such as A. arizonica (Powers and Backhaus, 1990), A. sisalana (Binh et al., 1990; Das, 1992), and A. parrasana (Santacruz-Ruvalcaba et al., 1999) in which MS medium without plant growth regulators was sufficient for root production. However, shoots of A. fourcroydes (Robert et al., 1987, 2006) and Agave Sisal (Hazra et al., 2002) required both 2,4-D and indoleacetic acid for rooting to occur. This suggests that the rooting of shoots of different species of agave is dependent on growth regulators. In conclusion, the results demonstrated the development of highly efficient protocol for plantlet regeneration. This protocol could be applied for massive plant propagation purposes for alcohol, fiber, and secondary metabolite production. Callus culture of $A$. americana could be a prerequisite for many techniques for in vitro manipulation, cellular line selection, and for genetic improvement programs.

\section{Literature Cited}

Arzate-Fernández, A.M. and R. Mejía-Franco. 2011. Embryogenic capacity of induced calli on zygotic embryonic axis of Agave angustifolia Haw. Rev. Fitotec. Mex. 34(2): 101-106.

Binh, L.T., L.T. Muoi, H.T.K. Oanh, T.D. Thang, and D.T. Phong. 1990. Rapid propagation of Agave by in vitro tissue culture. Plant Cell Tiss. Org. Cult. 23:67-70.

Castro-Concha, L., V.M. Loyola-Vargas, J.L. Chan, and M.L. Robert. 1990. Glutamate dehydrogenase activity in normal and vitrified plants of Agave tequilana Weber propagated in vitro. Plant Cell Tiss. Org. Cult. 22:147-151.

Chen, Y., X. Chen, F. Hu, H. Yang, L. Yue, R.N. Trigiano, and Z.M. Cheng. 2014. Micropropagation of Agave americana. HortScience 49: 320-327.

Das, T. 1992. Micropropagation of Agave sisalana. Plant Cell Tiss. Org. Cult. 31:253-255.

García, H.E., G.S. Méndez, and M.D. Talavera. 2010. El género agave spp. En México: Principales usos de importancia socioeconómica y agroecologíca. Revista Salud Pública y Nutrición, Edición Especial No. 5, 112.

Garriga, C.M., O.G. González, G.S. Alemán, C.E. Abreu, B.K. Quiroz, P.D.S. Caligari, and R. García-González. 2010. Management of auxincytokinin interactions to improve micropropagation protocol of henequen (Agave fourcroydes Lem). Chil. J. Agr. Res. 70(4):545-551.

Good-Avila, S.V., V. Souza, B.S. Gaut, and L.E. Eguiarte. 2006. Timing and rate of speciation in Agave (Agavaceae). Proc. Natl. Acad. Sci. USA 103(24):9124-9129.
Hazra, S.H., S. Das, and A.K. Das. 2002. Sisal plant regeneration via organogenesis. Plant Cell Tiss. Org. Cult. 70:235-240.

Infante, D., G. González, L. Peraza-Echeverría, and M. Keb-Llanes. 2003. Asexual genetic variability in Agave fourcroydes. Plant Sci. 164(2):223-230.

Madrigal-Lugo, R., F. Pineda-Estrada, and R. Rodríguez-De la O. 1989. Agave, p. 206-227. In: P.V. Ammirato, D.A. Evans, R.W. Sharp, and Y.P.S. Bajaj (eds.). Handbook of plant cell culture. Vol. 5. Ornamental Species, Chapter 9. McGraw-Hill, New York, NY.

Martínez-Palacios, A., M.P. Ortega-Larrocea, V.M. Chávez, and B. Robert. 2003. Somatic embryogenesis and organogenesis of Agave victoriae-reginae: Consideration for its conservation. Plant Cell Tiss. Org. Cult. 74:135-142.

McManus, J.F.A. 1961. Periodate oxidation techniques, p. 171-201. In: J.F. Danielli (ed.). General cytochemical methods. Vol. 2. Academic Press, New York, NY.

Murashige, T. and F. Skoog. 1962. A revised medium for rapid growth and bioassays with tobacco tissue cultures. Physiol. Plant. 15(3):473-497.

Nikam, T.D. 1997. High frequency shoot regeneration in Agave sisalana. Plant Cell Tiss. Org. Cult. 51:225-228.

Nikam, T.D., G.M. Bansude, and K.C. AneeshKumar. 2003. Somatic embryogenesis in sisal (A. sisalana Perr. Ex. Engelm). Plant Cell Rpt. 22(3):188-194.

Norton, M.E. 1986. Explant origin as a determinant of in vitro shoot proliferation in Prunus and Spiraea. J. Hort. Sci. 61:43-48.

Pence, V.C. 2011. Evaluating costs for the in vitro propagation and preservation of endangered plants. In Vitro Cell. Dev. Biol. Plant 47(1): 176-187.

Portillo, L., F. Santacruz-Ruvalcaba, A. GutiérrezMora, and B. Rodríguez-Garay. 2007. Somatic embryogenesis in Agave tequilana Weber cultivar azul. In Vitro Cell. Dev. Biol. Plant 43:569-575.

Pospíśilová, J., I. Tichá, P. Kadleček, D. Haisel, and Š. Plzáková. 1999. Acclimatization of micropropagated plants to ex vitro conditions. Biol. Plant. 42(4):481-497.

Powers, D.E. and R.A. Backhaus. 1990. In vitro propagation of Agave arizonica Gentry and Weber. Plant Cell Tiss. Org. Cult. 16(1):57-60.

Reyes-Zambrano, S., C. Lecona-Guzmán, J. Ambrosio Calderón, M. Abud-Archila, R. Rincón-Rosales, V. Ruíz-Valdiviezo, and F. Gutiérrez-Miceli. 2016. Plant growth regulators optimization for maximize shoots number in Agave americana L. by indirect organogenesis. Gayana Botánica 73(1):124-131.

Reynoso-Santos, R., J.A. García-Mendoza, W. López-Báez, and A. López-Luna. 2011. Identificación taxonómica de especies de agave utilizadas para la elaboración del licor Comiteco en Chiapas. Folleto Técnico $\mathrm{N}^{\circ} 14$ INIFAP

Rivera, G., V. Bocanegra-García, and A. Monge. 2010. Traditional plants as source of functional foods: A review. CYTA J. Food 8(2): 159-167.

Robert, M.L., J.L. Herrera, E. Castillo, G. Ojeda, and M.A. Herrera-Alamillo. 2006. An efficient method for the micropropagation of Agave species. Methods Mol. Biol. 318:165-178.

Robert, M.L., J.L. Herrera, F. Contreras, and K.N. Scorer. 1987. In vitro propagation of Agave fourcroydes Lem (Henequen). Plant Cell Tiss. Org. Cult. 8:37-48.

Robert, M.L., J.L. Herrera, J.L. Chan, and F. Contreras. 1992. Micropropagation of Agave spp., p. 307-329. In: Y.P.S. Bajaj (ed.). Biotechnology in agriculture and forestry. Vol 19. High-tech and micropropagation III. SpringerVerlag, Heidelberg, Berlin, Germany.

Rocha, M., A. Valera, and L.E. Eguiarte. 2005. Reproductive ecology of five sympatric Agave littaea (Agavaceae) species in central Mexico. Amer. J. Bot. 92(8):1330-1341.

Rodríguez-Garay, B., A. Gutiérrez, and B. AcostaDueñas. 1996. Somatic embryogenesis of Agave victoriae-reginae Moore. Plant Cell Tiss. Org. Cult. 46:85-87.

Sánchez-Urbina, A., L.M.C. Ventura-Canseco, T. Ayora-Talavera, M. Abud-Archila, M.A. PérezFarrera, L. Dendooven, and F.A. Gutiérrez Miceli. 2008. Seed germination and in vitro propagation of Agave grijalvensis, an endemic endangered Mexican species. Asian J. Plant Sci. 7(1):752-756.

Santacruz-Ruvalcaba, F., H. Gutiérrez, and B. Rodríguez. 1999. Efficient in vitro propagation of Agave parrasana Berger. Plant Cell Tiss. Org. Cult. 56(3):164-167.

Santacruz-Ruvalcaba, F. and L. Portillo. 2009. Thin cell suspension layer as a new methodology for somatic embryogenesis in Agave tequilana Weber cultivar azul. Ind. Crops Prod. 29(2):609-614.

Santíz, J.A., R. Rincón-Rosales, and F.A. GutiérrezMiceli. 2012. In vitro propagation of Agave grijalvensis an endemic species from Chiapas under special protection. Gayana Botanica 69 (numero especial):23-30.

SAS Institute. 1990. Statistic guide for personal computers, p. 1-102. Version 6.04. SAS Institute, Cary, NC.

Tejavathi, D.H., M.D. Rajanna, R. Sowmya, and K. Gayathramma. 2007. Induction of somatic embryos from cultures of Agave vera-cruz Mill. In Vitro Cell. Dev. Biol. Plant 43(5): 423-428.

Torres-Morán, M.I., M. Escoto-Delgadillo, S. Molina-Moret, D.M. Rivera-Rodríguez, A.P. Velasco-Ramírez, D. Infante, and L. Portillo. 2010. Assessment of genetic fidelity among Agave tequilana plants propagated asexually via rhizomes versus in vitro culture. Plant Cell Tiss. Org. Cult. 103(3): 403-409.

Valenzuela-Sánchez, K.K., R.E. Juárez-Hernández, A. Cruz-Hernández, V. Olalde-Portugal, M.E. Valverde, and O. Paredes-López. 2006. Plant regeneration of Agave tequilana by indirect organogenesis. In Vitro Cell. Dev. Biol. Plant 42:336-340.

Vázquez-Molina, D.E., A. De los Santos, K.A. Lecona-Guzmán, O. Súmano-Muñiz, M. Velázquez-Méndez, R. Rincón-Rosales, M.A. Oliva-Llaven, L. Dendooven, and F.A. GutiérrezMiceli. 2005. Sugar cane buds as an efficient explant for plantlet regeneration. Biol. Plant. 49(4):481-485

Yan-Mei, Z., L. Xin, C. Zhi, L. Jun-Feng, L. JunYing, and Z. Wen-Zhao. 2013. Shoot organogenesis and plant regeneration in Agave hybrid, No. 11648. Scientia Hort. 161:30-34. 